\title{
特別寄稿
}

\author{
査読の作法 \\ 早川智 \\ 日本大学医学部病態病理学系微生物学分野
}

\section{How to Review Biomedical Manuscripts}

Satoshi Hayakawa

Nihon University School of Medicine, Division of Microbiology, Department of Pathology and Microbiology

Peer review system is one of the most important processes to secure objectivity in sciences. Manuscripts submitted by any author, even if he or she is new comer or veteran, must be read critically by other scientists who have enough experience and extensive knowledge on related fields. While any person such as self-proclaimed scientists can publish their "new discoveries" in blogs, general books and/or open access predatory journals without undergoing review and editing process, their findings offer very little scientific information and occasionally cause health problems. Critical reading and reviewing scientific manuscripts takes times and efforts for scientists who would like to spend their own precious time for clinical or research activities. However any member of scientific community has moral obligations to read critically unpublished manuscripts as well as published ones in order to reach better scientific truth. In this sense, it is important to learn authentic manner to review manuscripts. For young scientists, peer-review experiences are also useful for responding to peer-reviewed opinions against their own manuscripts.

Key words: review, critical reading, scientific misconduct 査読, 批判的読解, 論文不正

(J. Nihon Univ. Med. Ass., 2019; 78 (4): 207-211)

\section{はじめに}

科学の本質は, 反証可能性である。自分の研究結果を 世に出すには発見に至る経緯と解釈や発展性を論文にま とめて発表し，第三者（読者）の批判を受けねばならな い，それ以前に，論文として科学雑誌に発表できる内容 かどうかを専門的知識をもった同僚科学者に評価して貪 う過程が必須である。このプロセスを経ないブログや一 般書で「新たな発見」を述べる自称科学者や残念なこと に医師もいる。言論の自由は先進国では担保されている とはいえ, 誤った概念や董付けの無い主張は科学の発展 を妨げるのみならず健康被害の原因となる，日大医学会 の会員の多くは日々の「教育・診療・研究」に忙殺され, あまり興味も無い他人の原稿を読むのは気が進まないか もしれない. しかし，同僚や後進，場合によっては先輩 の論文を読みこれに適切な批評を加えることは医学会会 員，さらに医学者コミュニティメンバーの義務でもある.

筆者自身の経験を言うと，米国留学時代こそ研究に専 念させてもらったが, 帰国して産婦人科の助手・講師時 代に当時の恩師佐藤和雄教授から，産婦人科のみならず 同先生が専攻される内分泌学や発生学の原著論文の査読 や公募シンポジウム, 科研費を始めとする研究費公募査 読の手伝いを命じられた。臨床では病棟医長を任せら
れた時期であり，実験時間のみならず睡眠時間や家族 との時間を削って査読にあたった。思い出してもつらい 毎日だったが, 自分と同世代あるいは少し上の少壮医学 者がどういった戦略で研究を進めてゆくのか, これを科 学の世界ではどのように評価し, どういった研究が高い 評価を受け，最終的に選ばれるのかを身をもって経験で きた，査読結果は特に英文の場合，佐藤教授がこれを添 削したうえで編集部に送っていたので，当時は二度手間 と思っていたが臨床同様, 大変な仕事こそ部下に経験さ せて最終的には自分が責任を取ることで後進を育てる という親心だったと思う。その後, Journal of Obstetrics and Gynecology（JOGR, 日本産科婦人科学会英文誌), Journal of Infection and Chemotherapy（JIC, 日本感染症学 会英文誌), American Journal of Reproductive Immunology などの Editorを経て, Immunological Medicine（日本臨 床免疫学会英文誌）の立ち上げに関わってきた。編集者 として遭遇したのは数多くの不正論文への対応である.

JOGR, JIC とも PubMed に掲載されて, Impact factor が 1 を越えた頃から，外国特にアジアの大国から後に述べる ような剽窃論文や捏造改窞論文が多数送られてくるよう になった。いずれも盗用検知システムを導入し，レフェ リーをして頂く先生に査読方法を周知し, 不正論文投稿 者に投稿停止や勤務先への通報などの処分を行うことで 
減少はしてきている。本誌においても，相澤信教授，高 山忠利教授, 山本隆充教授三代の編集委員長に副編集長 として仕え，その後数年編集委員長をさせていただいた。 本誌のような学内雑誌に意図的な不正論文が寄せられる 可能性は低いが，J-stage に掲載され，投稿者を必ずしも 日大医学会会員に限定しないことになると，外部から不 適切な論文が送られる可能性は十分にある.

\section{査読依頼が来たらどうするか}

大部分の科学者は, 査読を受けたこと, 査読に対応し たことはあっても査読の仕方を教わったこともなく, 成 書も少ない ${ }^{1)}$. 最近では, 出版社の査読ガイド ${ }^{2,3)}$ や科学 者のブログやホームページに查読例が記載されているも のがあるが, 残念ながら一部を除いて ${ }^{4)}$ 多くの場合, 匿 名で所属や身分がわからない5)。従って責任の所在もわ からない，筆者なりに過去 30 年にわたる査読歴の経験 を以下，述べたいと思う。

1 ）当該論文が自分に査読可能かどうかを，できるだけ 早く返事する。もし, 自分が学会の役員（理事，評 議員など）であれば, 原則断ってはいけない. 一般 会員からそれだけの学識を期待されているからであ る. 断る場合は単に忙しいという理由でなく, 何時 からどれ位の期間できないかを編集者に知らせる。

内容が専門外の場合もより適切と思われる查読者を 推薦する。

2 ）夕イトルが適切かどうか. 適切な区分かどうか. 查 読する価值があるかどうか. 要旨が適切に内容を反 映しているか. ここまでは, 査読依頼のメイルとと もに送られてくるので, これを読んで引き受けるか どうかを決める。

3 ) 緒言で, 当該領域の問題点と課題が適切に縓められ ているか. 結果と考察でこれに答えているか.

4 ）論文に新規性があるか.これは，論文のキーワード や結論を PubMed や医学中央雑誌で検索することで 容易に調べられる。もし，同じような事実が既に報 告されている場合, 著者がこれを知っていて引用し ないとすれば科学不正の一つ（新規性の詐称）と見 なされる。

5 ) 対象と方法が適切に選ばれているか. 研究方法に再 現性があるか. 試薬や器械の種類や購入先, 反応条 件や具体的に記されているか. 臨床の場合, ヘルシ ンキ宣言に則り，倫理委員会や患者さんの同意など の手続きが適切に行われているか. 基礎研究の場合 も, 動物実験委員会, 遺伝子組換え委員会, バイオ リスク管理委員会などの承認を得ているか（得てい る場合は日時と番号を記入)。

6 ）英語あるいは日本語が正しく書かれているか. ただ, 用語法が変であるという場合は具体的に指摘した方 が良い，更に，既出論文からのいわゆるコピー\&
ペーストが一定以上（通常 $25 \%$ 以上）の場合は剽 窃の可能性があり，40\%を越える場合はほぼ間違い ないので編集者にその旨を報告する， Material and methods の場合は同じ方法を用いるとある程度似て しまう可能性があるが, Introduction や Discussion で 一つ以上のセンテンスをそのまま持ってきている場 合は剽窃と見なされる。他人の所見を引用する場合 も必ず，文を言い換えかつ引用元を明らかにする必 要がある.

7 ) 図表が正しく描かれているか. 縦軸横軸の単位や目 盛りは正しいか．著作権の発生する図の引用は無い か（適切な引用許諾がなされているかどうか編集部 に確認を依頼する).

8 ) 統計的技法が正しく用いられているか. これが査読 者にも判らない場合は統計専門家に依頼するように 助言する.

9 ）英文が正しく書けているかどうかは筆者も native で はないので，自信が無いこともあるが不自然に感じ たら，近くの nativeに見てもらう。変な英語で一部 だけきれいな英語で書けている場合，大抵コピペで ある。その文章を google 検索すると, Wikipedia（英 語版）などに当たることが多いので，その時点で査 読を中止し Editor in Chief (EIC) に報告して処分を待 つ.

10）雑誌によっては，独自性や臨床的重要性，英文ので きや統計的手法を 5 段階あるいは 10 段階でつけさ せるところや, 全体の評価を 100 点満点で記入させ る場合もある、ただ，雑誌のレベルも勘案する。

これらの結果を勘案し，採否の意見を EICに送る。採 否自体はあくまで EIC の専権事項である。著者には知ら せず，親展で EIC 宛のコメントを記載する欄があるの で，これは素晴らしい論文なので載せる価值があるとか， このように程度の低い論文は当該雑誌の信用を損ねるの で，載せるべきでは無いとか書く，無断引用や剽窃，捏 造改竄などが疑われる場合はその旨を著者宛でなく 宛の欄のみに記入する，筆者の場合，興味深い論文を査 読させて頂き感謝するというセンテンスを最初に入れる ようにしている（但し，あまり酷いときや時間の無駄と 思うときは書かない)。一般にあまりにひどい場合は査 読者に送らず編集者のレベルでimmediate reject（門前払 い）にする。具体的には，英語（あるいは日本語）の意 味が分からないもの，倫理的に大きな瑕疪があるもの， 明らかな商業目的や疑似科学の論文などである。あまり, 変な論文を送ると，査読者に迷惑がかかるし，万一掲載 されてしまうと雑誌自体の価值を毀損するからである。

査読にあたっては下記の形で記入するのが一般的であ る.

1) 論文内容, 特に著者の言いたい新規性の要約

2 ) 論文の優れている点（たとえ, 却下や大幅修正でも 
何か良い所を探す)

3 ) しかし，(ここからが重要）以下のような問題点が あるので，ここを加筆修正すればアクセプトされる (あるいは再度審査を受けられる)。

major comments：実験方法や研究デザイン，倫理的 問題, 研究の独自性 (先行研究との関係), minor comments : 字句の修正, typo error, 図表のフォン トや解像度など技術的な点

重要なことは, 審査員が著者に直接言うのではなく, 編集委員長宛に「私は著者がこのようにすべきと考え る」．という形をとることである．時々，海外の有名英 文雑誌でも“You should”とか書いて来るレフェリー がいるが, “The authors are requested”とか“They are strongly recommended to”とか書くべきである。これが できていないと，著者や編集者からこの査読者は過去に トレーニングを受けていない, あるいはちゃんとした論 文を通したことが無いと思われる。日本語で，当該論文 の著者（三人称）と評価を行う筆者（一人称）がごっ ちゃになっている査読文を読んで仰天したことがあるが, こういった査読はレベルが低いので逆襲を受ける，査読 過程は一方通行でなく，相互にお互いの矛盾を見つけて ジャブを応答する「知的格闘技」だからである。そのた めにも，英語の場合は文法的に正しく，（自信が無いと きは native checkを受ける) ミススペルが無いように気 をつける。棟語の場合でも文体の統一（ですます体と だである体の混在，体言止め)，俗語の使用，誤字脱字 誤変換のないように気をつける，特に，本誌のように学 部学生や研修医, 大学院生が初めて投稿を行う場合, 初 学者が将来, 立派な医学者になるための登竜門であるこ とを十分に理解し, 懇切丁寧に指導する。他の雑誌でも 冷笑的侮藿的な表現や主観的な表現は極力避ける。多く の雑誌ではレフェリーの内容を見て，担当編集者が 1 か ら 3 の評点をつけるが, これはその雑誌が存続する限り 消えないので，いい加減なことを書くと，当該領域での 自分自身の医学者としての評価を下げることになる。評 価内容は公表されないが，JOGRのように年間の査読数 と審査内容で Best reviewer を表彰する雑誌もある。本誌 もかつて筆者が EIC だったときにこの制度を導入したが, 後任の方のときに無くなってしまったのが残念である.

\section{剽窃の検索}

英語を母語としない研究者の場合, 出来合いの英語論 文やネット上のサイトからコピペで論文を作成すること がある。かつて，日本人に英作文は無理だから英借文せ よと言う指導者や，よくある言い回しを集め, これを切 り貼りすれば論文ができるなどとした参考書があったが, これは嘘である。たとえ症例報告であっても，自分たち の独自の考察を他の論文の言い回しを借りて述べること はできない，実際，出典を明記せずに他人のアイデアを
引用することは剽窃行為になる。現在欧米あるいは日本 の大部分の科学雑誌は, Cross Check という剽窃探知シ ステムを導入しており, レフェリーに回る前に編集者レ ベルでこれを検索する。本誌も含めて, J-Stageに収載 されている国内の科学雑誌もこれを利用できる。もし， 盗用が明らかになった場合, 論文が reject されるのみな らず，著者は（共著者の全員に対して）数年の投稿禁止 処分や所属機関への通達といった処分が科される。これ は編集者の仕事であり査読者自らが検察官になる必要は 無い.しかし, クロスチェックの膨大なデータベースは 日本語に対応しておらず，図表の二重投稿や盗用も見抜 くことはできない，査読者は投稿された論文のみならず 文献表にある参考文献や，さらにPubMed で関連論文を 見て不適切な引用が無いか確認する。

\section{レフェリーの守秘義務}

査読を行う論文が来たら，その内容を不用意に第三者 に漏らしてはならない. かつて, 筆者が EIC をしてい たときに，とある査読委員が査読中の原稿を所属教室の 抄読会の材料に使い, これが外に漏れて問題となった事 例がある．若手の教室員の教育のために査読を手伝って もらう場合には, 当該医局員に守秘義務についても十分 教育する。できれば，担当教授宛でなく，査読を行う若 手教室員あてに査読依頼を送ってもらい，教授はその内 容をダブルチェックする形が望ましい. 学会などで, 投 稿相手に会うことがあったとしても「先生のとこの原稿 見てるよ!」などと軽口を吒いてはいけない，その場で は「一つお手柔らかに」などと言われても, 内心科学者 としての信頼性が低い奴だと思われるのがオチである。

\section{修正論文が来たらどうするか}

コメントに対し，著者が一つ一つ丁寧に (point by point) で反応しているか. 修正箇所が明記してあるかど うか. を確認する。 反論に正当な根拠があって, 単なる 言い訳や言い逃れでない場合は著者の意見を受け入れる ことも大事である。指摘を無視している場合は編集長宛 に受け入れられないと伝える. 修正箇所で気になるとこ ろがあれば，ここに対する査読意見は述べても良いが, 前回読んで気がつかなかった所を指摘するのはルール違 反（一事不再理）であるので厳に慎む.

\section{おわりに}

古来和をもって尊しとする日本人は, 何事も争い無く 済ますのが最善と考える傾向があるが, 科学の世界は厳 しい相互の批評があって初めて真実に至る。筆者が理 事・監事を勤める日本臨床免疫学会のモットーは“No discussion, no science”である.もちろん, 科学上の討論 は個人の間の親踈や立ち位置とは無関係にあるべきであ り師匠・先輩, 親友の研究であっても科学的に問題あり 
Table 1 Recommendations by referee

\begin{tabular}{|l|l|}
\hline Accept & このまま掲載してよい. \\
\hline minor revision & 語句の訂正や, 簡単な加筆, 図表の修正などが必要. \\
\hline major revision & $\begin{array}{l}\text { このままでは掲載が困難なので大幅な加筆が必要. } \\
\text { 追加実験や, 追加データの提出を要求することもある. }\end{array}$ \\
\hline Reject & $\begin{array}{l}\text { 本誌の掲載には相応しくない. (大幅な加筆を行えば再投 } \\
\text { 稿可能な場合と, 二度と投稿しないで欲しい場合がある) }\end{array}$ \\
\hline Immediate Reject & $\begin{array}{l}\text { 査読者に送る前にリジェクトする.よほど内容がひどい場 } \\
\text { 合や倫理的問題, 科学不正が疑われるもの. } \\
\text { 後者の場合は編集会議から処分が科せられる. }\end{array}$ \\
\hline
\end{tabular}

Table 2 Frequently used referee phrases

General comments（総評と審査意見）

\begin{tabular}{|c|c|}
\hline & よく使う表現 \\
\hline $\begin{array}{l}\text { 論文内容の概略 } \\
\text { (投稿の時点は査 } \\
\text { 読の前なので, 著 } \\
\text { 者を主語にする場 } \\
\text { 合, 実験や臨床行 } \\
\text { 為は過去形. 論文 } \\
\text { や議論が主語の場 } \\
\text { 合は現在形) }\end{array}$ & $\begin{array}{l}\checkmark \text { The presented manuscript describes experimental results obtained from in vitro study of ... } \\
\checkmark \text { Gon et.al reported ... as the first time, } \\
\checkmark \text { It describes possible application of ... technique for managements of advanced ...... malignancies. } \\
\checkmark \checkmark \text { The authors argue possible importance of ... in the pathophysiology of ... } \\
\checkmark \text { This manuscript aim at ... } \\
\checkmark \checkmark \text { The authors proposed a new application of XXX 's operation for intractable cases with .... } \\
\checkmark \text { The authors identified (revealed, demonstrated, clarified) novel mechanism of ... } \\
\checkmark \text { They contend (advocate) importance of ... }\end{array}$ \\
\hline $\begin{array}{l}\text { 論文の評価 } \\
\text { (現在形) }\end{array}$ & $\begin{array}{l}\checkmark \text { This manuscript is well designed and beautifully written. However it requires some revisions as listed below. } \\
\text { (一番よく使われる表現) } \\
\checkmark \text { This is an interesting (important, novel, innovative) observation (hypothesis, contribution, finding ) in the field of } \\
\text { clinical immunology. However, it contains several problems (shortcomings, concern) as listed below. } \\
\checkmark \checkmark \text { This manuscript is not informative for NUJM readers. } \\
\checkmark \checkmark \text { The author's interests are not compatible to the journal policy. } \\
\checkmark \text { I cannot recommend publication of this manuscript for following reasons. } \\
\checkmark \checkmark \text { This manuscript can be accepted after fundamental revision. } \\
\checkmark \text { This manuscript only requires minor revision as listed below. }\end{array}$ \\
\hline
\end{tabular}

Major comments (重要な査読意見)

\section{よく使う表現}

\begin{tabular}{|l|l|}
\hline & \multicolumn{1}{c|}{ よく使う表現 } \\
\hline & $\checkmark$ Their results are not conclusive for the paucity of the samples. \\
& $\checkmark$ The authors' conclusion does not supported by their own data. \\
\multirow{4}{*}{$\begin{array}{l}\text { Major revision } \\
\text { (大幅な修正) }\end{array}$} & $\checkmark \begin{array}{l}\checkmark \text { Their discussion lacks logical flow based on their own findings. } \\
\text { articles. }\end{array}$ \\
& $\checkmark$ I have some difficulty to catch up the author's logic. \\
& $\checkmark$ The authors employed non-quantitative RT-PCR to evaluate mRNA expression in the samples. They are requested \\
& to show the results based on state-of-the art methods such as real time PCR.
\end{tabular}

再査読の場合

\begin{tabular}{|l|l|}
\hline & \multicolumn{1}{|c|}{ よく使う表現 } \\
\hline Accept & $\checkmark$ The presented manuscript is revised adequately. \\
& $\checkmark$ I appreciate the authors for their collaboration. \\
\hline \multirow{2}{*}{ Reject } & $\checkmark$ I regret the authors did not improve their manuscript. \\
& $\checkmark$ The authors failed to respond my major comment 3. \\
\hline
\end{tabular}


と考えたらこれを指摘・修正することを遠慮してはなら ない. 悠しい相互批判を経て初めて科学論文の質の向 上が期待できるし，本誌のような学内雑誌から Nature, Science のような一流誌まで査読の作法は変わるところ が無い.

科学論文の批判的読解というのは, 欧米では学部学生 の時からの必修事項である。多くの方は教室や研究室の 抄読会で経験されていることであろう。ただ，「批判」 というのは Kritisches Lesen あるいは Critical reading の明 治時代の誤訳であり，対象をけなす，㲘めるというニュ アンスはない. 相手の論を踏まえ, 内容を十分に理解し, さらに自分の意見を付加してより高みを目指すというソ クラテスの問答からアリストテレスの弁論術，そしてへー ゲルによって集大成された弁証法の過程である ${ }^{6}$ 。従っ て，このような学問上の討論を楽しみ，真実に至ること が知的生活者の喜びとなるであろう。査読のお礼として 中国の雑誌のように, パンダの切手や美麗な新年カード を送ってくれるところもあるが，原則的には無料奉仕で ある。しかし，世界中で著者と編集者以外に知り得ない 新発見を共有できることは査読者の最大の特権であり，

スポーツと同じように攻守双方を経験することで自分の 実力を磨くことができる。最後に筆者の敬愛するオルテ ガの言葉を挙げる.「課された義務をこそ自己の特権と して認識すること」7,8)
本論文に関する COI はありません.

\section{文献}

1）CS ラングハム。国際論文 English 查読・執筆ハンドブッ ク. 医歯薬出版株式会社, 2011/10/05.

2）エルセヴィア．査読をする https://www.elsevier.com/ja-jp/reviewers/how-to-conduct-areview

3) ワイリー。サイエンスカフェ. http://www.wiley.co.jp/blog/pse/?p=2254

4）太田充恒. 産総研 太田充恒のページ，英語論文の査読 表現集.

https://staff.aist.go.jp/a.ohta/japanese/study/Review_ex_top. $\mathrm{htm}$

5）匿名ブログ. 査読のやり方，査読レポートの書き方 日 本の科学と技術.

http://scienceandtechnology.jp/archives/12812

6）廣松渉．新哲学入門。岩波書店, 1988.

7）オルテガ (著), José Ortega y Gasset (原著)，寺田和夫 (翻訳). 大衆の反逆. 中公クラシックス 新書, 2002.

8）本稿の一部は日本産婦人科医会ホームページ ドクター 早川の論文セミナーに準拠しています。

http://www.jaog.or.jp/learning/dr-\%E6\%97\%A9\%E5\%B7\%9 D\%E3\%81\%AE\%Е7\%A0\%94\%Е7\%A9\%B6\%Е3\%82\%BB $\% \mathrm{E} 3 \% 83 \% 9 \mathrm{~F} \% \mathrm{E} 3 \% 83 \% 8 \mathrm{~A} \% \mathrm{E} 3 \% 83 \% \mathrm{BC} /$ 